\title{
Audiovisual translation of puns in animated films: strategies and procedures
}

\author{
Elena Aleksandrova \\ Russian Presidential Academy of National Economy and Public Administration, Moscow, Russia \\ elena751@mail.ru
}

\begin{abstract}
The translation of the pun is one of the most challenging issues for translators and interpreters. Sometimes, puns, especially those containing realia, are considered to be untranslatable. Most translation strategies and procedures offered in previous findings for the translation of realiabased puns are not appropriate for audiovisual translations of animated films, for either dubbing or subtitling, because of the specificity of the target audience, and the genre. The problem of choosing the most relevant strategy and procedures for realia-based puns is underexplored. To narrow the gap, metamodern and semiotic approaches are applied to the translation of puns. In accordance with the semiotic approach, a pun is considered as a type of language game based on the use of the asymmetry of the form, and the content of the sign. The "Quasi-translation" strategy discussed in this paper reflects the metamodern attitude towards the game, whereby "game change" is one of the basic postulates. "Quasi-translation" involves three types of translation procedures: quasi-localisation, quasi-globalisation, and quasiglocalisation. The term "quasi-glocalisation" is also used to denote the general strategy for the translation of audiovisual works containing realia-based puns, which involves: 1) oscillation between the need to adapt the translation to the target culture, and the need to preserve the culturally-marked components of the original; and 2) the reproduction of "atmosphere" (the common reality of the perceiver and the perceived). This insight can be used by audiovisual translator-practitioners, and university teachers in the course of translation theory and practice.
\end{abstract}

Keywords: metamodernism, translation, pun, quasi-glocalisation, realia.

\section{Introduction}

Humour is becoming "a symptom of research trend in translation studies" (Martínez Sierra \& Zabalbeascoa 2017: 9). In the era of information technologies, when machine translation has become an essential tool for professional translators, humour is still an area that attracts the attention of many scholars and practitioners. Various studies devoted to the translation of verbal humour are based on different scientific approaches and theoretical models. 
The theoretical basis of recent studies devoted to the audiovisual translation of puns is presented in the General Theory of Verbal Humour (GTVH) (see Attardo \& Raskin 1991) and wide and narrow classifications and typologies created on the basis of different languages and research materials (see Guiraud 1976; Chiaro 1992; Lew 1996; Alexander 1997; Ritchie 2004; Aleksandrova 2018b).

The pun is one of the most popular forms of verbal humour. It has always been, and continues to be, one of the most problematic issues in translation (Aleksandrova 2018a: 5). Puns based on the use of homonyms or paronyms cause the greatest difficulties for translators. The translation of polysemic words, one of the meanings of which in the Source Language (hereinafter referred to as SL) is not represented in the Target Language (hereinafter referred to as TL), or idioms, which do not have a direct match-idiom in the TL, is also problematic. Some studies consider puns to be untranslatable (e.g. Delabastita 1993: 173-177; Pisek 1997: 37), while others claim that nearly all puns can be translated (e.g. Gottlieb 1997b: 226; Schröter 2010: 142-143). Both studies, based on different language pairs and type of works - that is, literary (see, e.g., Delabastita 1997; Veisbergs 1997; Henry 2003; Low 2011; Vandaele 2011; Chiaro 2017) and audiovisual (see, e.g., Gottlieb 1997b; Pisek 1997; Schröter 2005, 2010; Dore 2010, 2019; Schauffler 2015; De los Reyes Lozano 2017; López González 2017) - reflect different approaches to the issue.

In this paper, an approach based on the combination of metamodern and semiotic principles is applied to the audiovisual translation of puns in animated films. The paper is devoted to the analysis of the role of a translator, and of his/her attitude towards the original text, towards the sender of the Source Text (hereinafter referred to as ST) and towards the receiver of the Target Text (hereinafter referred to as TT).

Yaguello (2003: 26) considers language as a game. In light of semiotics, the pun is defined as a game based on the asymmetry of form and content of the sign resulting in a new speech form. According to Yaguello (2003: 26), the essence of the game is a combination of rapid, vortex movement and rules, freedoms and restrictions. Freedom and restriction also become integral components of the process and the result of the translation of a pun. The ratio of freedom and restriction depends on many factors, such as the pragmatics of the pun, its context, language pair, etc. The translator is oscillating between freedom and restriction, between literal (direct) and free translation when looking for the right solution.

Oscillation is one of the basic principles of metamodernism (Bunnell 2015), together with the "atmosphere," which is defined by Böhme (1993: 122) as the common reality of the perceiver and the perceived: "it is the reality of the perceived as the sphere of its presence and the reality of the perceiver, insofar as in sensing the atmosphere s/he is bodily present in a certain way". Böhme (1993: 125) considers "atmospheres" to be the "primary 'objects' of perception", "what is first immediately perceived".

Metamodernism is considered to be a new movement based on modesty, sincerity, engagement, authenticity, hope, universal truths, and openness, in the works of the researchers such as Vermuelen \& Akker (2010), Febleron (2012), Abramson (2014), Bunnell (2015), Freinacht (2015), Turner (2015), Goryunov (2017), Yousef (2017). It is also one of the types of postmodernism (see Amian 2008; Pavlov 2018). Yousef notes that metamodernism is a recent movement in various spheres of human philosophy, art, literature, architecture, politics and many other human activities; post-postmodernism and neomodernism are also terms used interchangeably with metamodernism to describe the developments that emerged from or came about as a reaction to postmodernism (Yousef 2017: 37).

According to the principles of metamodernism, the need to find the right balance when oscillating between freedom and restriction, and to reproduce the "atmosphere" of the original is considered to be the main purpose of the metamodern approach to the translation of the pun. 
This approach becomes one more way of expressing the classical dilemma between literal vs. free translation, foreignisation vs. domestication.

To clarify and describe the ideas of the pun translation "balance" and "atmosphere", a structural semiotic approach can be used. A semiotic theory introduced by Peirce (1934: 484), who identified three semiotic elements, namely the sign, object, and interpretant, was further developed by Morris (1938), who distinguished three dimensions of semiosis: the syntactic (relations between signs), the semantic (relations between the signs and objects), the pragmatic (relations between the sign and interpreter). The theory was later on systematised by Eco (1975) in interpretative semiotics on the basis of an analysis of literary works. This approach was applied to translation theory and practice (see Jacobson 1959; van Kesteren 1978; Toury 1986; Eco 2001; Cosculluela 2003; Garbovskiy 2004; Stecconi 2004).

In a semiotic approach, translation is defined as a complex interpretative system, i.e. a system-based activity, making it possible to interpret the signs of one semiotic system by the signs of another semiotic system (Garbovskiy 2004: 243). In accordance with a semiotic approach, the translation of the pun is considered as a manipulation of signs composing the core of the pun, which can be realised in two ways: 1) between the semiotic systems of the SL and the TL; and 2) inside the system of the TL.

The application of a combination of metamodern and semiotic approaches to audiovisual translation of verbal humour in animated films, which is complicated by the use of realia-based puns and intersemiotic puns, makes it possible to describe the process of seeking balance between translation freedom and restriction on a structural basis, by considering creative solutions from audiovisual translators.

\section{Method}

The metamodern-semiotic approach to translation is investigated in audiovisual translations of puns represented in animated films. The works devoted to the translation of puns in animated films are based on different language pairs and consider different aspects of the problem (see Schröter 2005; Dore 2009; De Rosa 2014; Manca \& Aprile 2014; Minutella 2014; De los Reyes Lozano 2017; López González 2017). In this paper, the original English pun-based jokes represented in animated films are compared to their Russian and French translations.

\subsection{Material}

The study is based on 30 examples of pun-based jokes in English from 22 animated films released between 1970 and 2018 ("The Aristocats" (1970); "An American Tail" (1986); "Beauty and the Beast" (1991); "Aladdin" (1992); "Toy Story" (1995); "Hercules" (1997); "Shrek (2001)"; "Finding Nemo" (2003); "The Lion King" (2004); "Madagascar" (2005); "Bee Movie" (2007); "Ratatouille" (2007); "Toy Story 3" (2010); "Winnie the Pooh" (2011); "Frozen" (2013); "Lava" (2014); “The Penguins of Madagascar" (2014); "Hotel Transylvania 2" (2015); "Moana" (2016); “Zootopia" (2016); "Early Man" (2018); "Ralph Breaks the Internet" (2018)). The films were selected by the method of continuous sampling (the selection of all appropriate units in the order they are represented in the sources relevant to the study), and their Russian and French (dubbed and subtitled) translations.

\subsection{Procedure}

The original versions and the Russian and French translated versions were compared and analysed in order to 1) identify the problems of audiovisual translation of animated films; 2) reveal the strategies used by Russian and French translators; 3) reveal the translation procedures 
used to reproduce puns; 4) identify the general strategy and procedures of audiovisual translation of realia-based puns.

\section{The specificity of audiovisual translation of animated films}

When translating an animated film for dubbing or subtitling, it is necessary to take into account the following aspects: 1) the characteristics of the audience (recipient); 2) the specifics of the genre of the work (message).

\subsection{The particularities of the audience}

When translating an animated film, first of all, you need to focus on the recipient of the message. The cognitive features of children, for whom the animated film is created, determine both the very explicit video sequence of the animated film and the language features of the film script (Garbusenok \& Znachenok 2016: 134).

The following characteristics of animated films were revealed by Garbusenok \& Znachenok (2016): the use of clear and simple vocabulary, lack of unclear terms and archaic words, a reasonable use of neologisms, and a lack of a large number of stylistic figurative means. At the same time, they mention the widespread use of adjectives, comparisons, personifications, repetitions, phraseological units, proverbs, and songs.

But the most problematic issues for translators are the connection with national culture and the use of jokes especially those that are pun-based, and which cannot be omitted. Not every translated version of a pun will be appropriate for an audience of children.

\subsection{The particularities of the genre}

When translating an audiovisual product, both for subtitling and for dubbing, the translator faces the problem of seeking a balance between freedom and restrictions. The translator should take into account a lot of extra linguistic and technical details that are not important for other types of translation. The problem with audiovisual translation is the frequent lack of time and space. The translator has to pay attention to the compatibility of the TT with visuals, gestures, facial expressions and even lip synchronisation.

Audiovisual translation is just one part of a more complex process with other factors involved. The work of the translator depends on the modality (dubbing or subtitling). This problem attracts the attention of many scholars who reveal different implications of humour dubbing (see, e.g., Zabalbeascoa 1996; Dore 2009, 2010; Chiaro 2010; Bucaria 2007, 2017; Brisset 2015) and subtitling (see, e.g., Gottlieb 1997a, 1997b; Hurtado \& Molina 2002; Spanakaki 2007; Pedersen 2011; Bolaños García-Escribano 2017). Scholars report different verbal humour strategies for dubbing (see Chiaro 2010: 6-7), subtitling (see Gottlieb 1997: 210; Hurtado \& Molina 2002), dubbing/subtitling (Bassnett 1980: 22; Fuentes 2010; Díaz Pérez 2017). But in either modality, the translator of a pun in an animated film has the last word.

It should be noted that in Russia, dubbed versions of both movies and animated films are more popular, while subtitling acceptance is not as frequent. In subtitled versions, puns are mostly (but not always) translated literally. The comparative analysis of the original puns and their Russian translations for subtitling and for dubbing showed that only in two cases in the dubbed versions did the translator use the non-pun replacement, while in the subtitled version, the puns were preserved. It should also be noted that the same text can be used both for dubbing and subtitling (only four animated films with differently dubbed and subtitled versions were found). Sometimes different translation companies provide different subtitled and dubbed versions. 


\section{The audiovisual pun translation strategies}

Puns cannot be removed from animated films, because they are connected with the context and can play a broad spectrum of roles. Hence, there are different pun translation strategies: omission, literal translation with or without commentary, translation-rendering (representation of the pun in the TL provided with an explanation of its ambiguity), and free translation. A pragmatically adequate and, at the same time, semantically and syntactically equivalent translation cannot be considered to be a relevant strategy, because it is not possible to reproduce in the TL both signs used to create a pun in the SL. Not all the above-mentioned translation strategies are, therefore, appropriate for the audiovisual translation of puns. The research revealed three main strategies used in audiovisual translations of animated films: 1) free translation with a non-pun replacement; 2) literal translation; 3) "quasi-translation".

\subsection{Translation strategies and attitudes towards the game}

In this section, we develop the approaches to the translation of the pun that reflect the attitude to the "game". In metamodernism, the "game" is considered to be "the fundamental, interactive process by which human beings and other living creatures either become happy or suffer" (Freinacht 2015). Freinacht (2015) distinguishes different attitudes to the game in metamodernism: denial, acceptance, and change.

\section{Game denial in translation}

Game denial refers to cases of complete negation of the game, or the inability to perceive its rules. When translating a game, the denial of a game leads to the omission of a pun or to its non-pun replacement with contextually suitable text.

Omission of a pun. Consider an example from the animated film "The Lion King" (2004) with parallel English and Russian subtitles, where omission is used:

\section{Example 1}

\begin{tabular}{|l|l|l|}
\hline SL (Eng.) & TL (Rus.) subtitling & Gloss \\
\hline - Hakuna matata? & - Акуна Матата? & Hakuna matata? \\
- Yeah. It's our motto. & - Ну да. Это наш девиз. & Yeah. It's our motto. \\
- What's a motto? & & \\
- Nothing. What's a motto with & & \\
$\begin{array}{l}\text { you? } \\
\text { - Kid, these two words will } \\
\text { solve all your problems. }\end{array}$ & $\begin{array}{l}\text { Поверь мне эти два слова } \\
\text { решат все твои проблемы. }\end{array}$ & $\begin{array}{l}\text { These two words will solve all } \\
\text { your problems. }\end{array}$ \\
\hline
\end{tabular}

In the TT, the second meaning of the original pun 1) what's a motto? 2) what's the matter? was lost, the phrase "Nothing. What's a motto with you?" was not translated.

Several versions of Russian translation for dubbing and subtitling of this animated film using different strategies were found.

Non-pun replacement. In the following version of the dubbed translation, the pun was replaced by a non-punning text suitable for the context in the TL:

\section{Example 2}

\begin{tabular}{|l|l|l|}
\hline SL (Eng.) & TL (Rus.) dubbing & Gloss \\
\hline- Hakuna matata? & - Акуна Матата? & Hakuna matata? \\
- Yeah. It's our motto. & - Да, это наш девиз. & Yeah. It's our motto. \\
\hline
\end{tabular}




\begin{tabular}{|l|l|l|}
\hline - What's a motto? & - Что это такое? & What is this? \\
- Nothing. What's a motto & - Беспроблемная & Unproblematic philosophy. \\
with you? & философия. & \\
- Kid, these two words will & - Знаешь, детка, эти два \\
solve all your problems. & слова решают все проблемы. & $\begin{array}{l}\text { You know, kid, these two words } \\
\text { will solve all your problems. }\end{array}$ \\
\hline
\end{tabular}

\section{Game acceptance in translation}

In translation, game acceptance refers to the situation where the translator accepts the rules proposed by the author and creates a literal translation (direct, or word-for-word, translation in which the comic effect, as a rule, is not preserved) which would not be successful. Consider the episode from the animated film "Hotel Transylvania 2" (2015):

\section{Example 3}

\begin{tabular}{|c|c|c|}
\hline SL (Eng.) & TL (Rus.) subtitling & Gloss \\
\hline $\begin{array}{l}\text { All right, fine. How do you } \\
\text { do this? }\end{array}$ & $\begin{array}{l}\text { - Хорошо, отвечу. Да как ты } \\
\text { это делаешь? }\end{array}$ & $\begin{array}{l}\text { Well, I will answer. How are } \\
\text { you doing this? }\end{array}$ \\
\hline $\begin{array}{l}\text { - Yeah, got it. Maybe you } \\
\text { should just get Bluetooth. } \\
- \text { Okay. Blue Tooth, come } \\
\text { over here. So, now what? (see } \\
\text { Figures 4) }\end{array}$ & $\begin{array}{l}\text { - Может, вам больше } \\
\text { подойдет Bluetooth? } \\
\text { - Ладно, Голубой } \\
\text { субб, иди } \\
\text { сюда. И что теперь? }\end{array}$ & $\begin{array}{l}\text { Maybe you should just get } \\
\text { Bluetooth. } \\
\text { Okay, Blue Tooth, come over } \\
\text { here. So, now what? } \\
\text { (This pun is based on the } \\
\text { phonetic similarity of the noun } \\
\text { Bluetooth (wireless technology) } \\
\text { and the film character's name } \\
\text { Blue Tooth.) }\end{array}$ \\
\hline
\end{tabular}

\section{Game change in translation}

The game change concerns cases where the translator is changing the rules of the game proposed by the author and, at the same time, trying to preserve the author's creative idea. In translation, game change can be connected with the changing of 1) the form and/or content of $\operatorname{sign}(\mathrm{s})$ used to create the pun; and/or 2) the pun-creating mechanism. The translation related to such changes is called a pragmatically appropriate and semantically "quasi-equivalent" translation (hereinafter referred to as "quasi-translation"). The prefix "quasi" was used by Eco (2003), where he concluded that a translation can never "say the same thing": however, it can "say almost the same thing" (Eco 2003: 6). For example, consider the translated versions of the above pun from the animated film "The Lion King" (2004):

\section{Example 4}

\begin{tabular}{|l|l|l|}
\hline SL (Eng.) & TL (Rus.) subtitling & Gloss \\
\hline - Hakuna matata? & - Акуна Матата? & Hakuna matata? \\
- Yeah. It's our motto. & - Ага, это наш девиз. & Yeah. It's our motto. \\
- What's a motto? & - Что такое “девиц”? & What is “damsel”? \\
- Nothing. What's a motto with & - Где это ты девиц увидел? & $\begin{array}{l}\text { Where have you seen the } \\
\text { damsels? }\end{array}$ \\
$\begin{array}{l}\text { you? } \\
\text { - Kid, these two words will } \\
\text { solve all your problems. }\end{array}$ & - Парень, эти два слова решат & $\begin{array}{l}\text { Guy, these two words will solve } \\
\text { all your problems. }\end{array}$ \\
\hline
\end{tabular}


Being "quasi" means "being partly or almost", so "quasi-equivalent" is partly equivalent, because only one core sign of the pun is preserved in the TT (here - Ah! Motto? / A! Девиз?). In this version, Russian paronyms девиз [motto] and девии [damsel] are used.

\section{2. "Quasi-translation" and free translation}

"Quasi-translation" is a game that consists of the fact that the translator does not only reproduce the game of signs represented in the ST, but also creates a new one (Aleksandrova 2018a: 8). This concept is similar to the concept of free translation. Newmark (1988: 45) gives the following definition of free translation: "Free translation: it produces the TL text without the style, form, or content of the original". There is, however, a difference between these two strategies. Free translation deals with the replacement of both pun-creating signs in the TL. Quasi-translation deals with the situations when one sign is needed to be preserved in the TL, where it can be replaced by a synonym, a hyponym, a hypernym or any other word in the same semantic field.

Consider an example from the animated film "The Lion King" (2004), for which two translations of this pun were found:

\section{Free translation}

\section{Example 5}

\begin{tabular}{|l|l|lr|}
\hline SL (Eng.) & TL (Rus.) dubbing (version 1) & Gloss \\
\hline - Well! The buzz from the & - Шимпанзе кривляются. & Chimpanzees make faces. \\
bees is that the leopards are in \\
a bit of a spot. & $\begin{array}{l}\text { Жирафы отвлекаются. Слоны } \\
\text { абсолютно все помнят, вот } \\
\text { только что? Я позабыл... }\end{array}$ & $\begin{array}{l}\text { Elephants ares distracted. } \\
\text { everything, but what? I forgot... }\end{array}$ \\
\hline
\end{tabular}

\section{“Quasi-translation”}

\section{Example 6}

\begin{tabular}{|l|l|l|}
\hline SL (Eng.) & TL (Rus.) dubbing (version 2) & Gloss \\
\hline $\begin{array}{l}- \text { Well! The buzz from the } \\
\text { bees is that the leopards are in } \\
\text { a bit of a spot. }\end{array}$ & $\begin{array}{l}- \text { Говорят, пятнистые леопарды } \\
\text { сильно себя запятнали. }\end{array}$ & $\begin{array}{l}\text { They say spotted leopards have } \\
\text { spotted themselves too much. }\end{array}$ \\
\hline
\end{tabular}

In the free translation version, none of the meanings of the polysemic word spot (first, a small round or roundish mark, differing in colour or texture from the surface around it; and second, a blemish on someone's character or reputation) used to create the original pun were preserved in the TT.

In quasi-translation, the meanings of the polysemic word запятнать (first, to spot, to stain; second, to disgrace, to tarnish, to sully), which have similar semes, were used to create a new pun in the TL. The Russian verb запятнать, used in the TT, has similar semes to the English noun spot, used in the ST.

The above free translation can also be considered to be successful, despite the fact that the pun is replaced by rhymed text, which does not have any meanings in common with the original pun. It should be noted that free translation is not always appropriate, because the translator often goes beyond the scope of translation, and the translated text, in this case, has nothing to do with the original one. In these cases, free translation becomes game denial. 
In "quasi-translation", the translator is changing the game, but at the same time he is trying to keep the author's original idea and style. When speaking about axioms of metamodernism, Freinacht (2015) gives the following examples: "Don't hate the player. Don't hate the game. Know the game. And play to change it. Because you love the players" (Freinacht 2015). In the case of translation, these axioms can be transformed into: "Don't hate the author, don't hate the pun, understand the pun, and play to change it, because you are loyal to the author and love the recipient." "Quasi-translation" assumes changing the game (pun) presented in the SL, when the translator focuses on the author, the message, and the recipient, and tries to reproduce its "atmosphere" in the TL, which involves humorous ambiguity and the non-evident content of the original.

The representation of the ST "atmosphere" in the TT, and identifying the common source of the experience of unity are the main aims of metamodern translation. In this way, the translator reaches a new quality of translation and avoids extremes such as literal translation or extremely free translation. The experience of unity is related to humorous ambiguity and its effect on emotions. Tănase (2018: 104) notes that humour has always travelled between cultures and will continue its intercultural journey, which brings people together, regardless of how far apart they might think they are.

Free translation is usually considered to be a pragmatically oriented strategy, where the main aim of translation is to preserve the communicative effect of the original. However, the research, based on an analysis of Russian and French translations of pun-based jokes included in animated films in English, revealed that sometimes the translator goes beyond the scope of translation by representing in the TT a set of phrases that have nothing to do with the original: neither contextual meanings nor comic effect.

"Quasi-translation" is defined here as the most relevant audiovisual translation strategy. At the same time, it should be noted that in recent years, the quality of the translation of puns in animated films has improved (see "Hotel Transylvania 2" (2015); "Moana" (2016); "Early Man" (2018)). Translators are trying to create a text that meets the requirements of the audience. The tendency to accept "quasi-translation" as the main audiovisual pun translation strategy is becoming increasingly salient.

\section{Quasi-translation procedures}

Newmark (1988: 81) distinguishes between translation methods (strategies here) and translation procedures in the following way: "While translation methods relate to whole texts, translation procedures are used for sentences and the smaller units of language". In the case of puns, strategy refers to the pun itself, procedure refers to the pun-composing signs, and the term "general strategy" can also be considered, referring to the whole audiovisual product.

It was revealed that, in order to preserve the form and meaning of pun-composing signs in the TL, both transformation procedures and deformation procedures (conscious distortion of any parameter of the text of the original, justified by the desire to solve the global translation problem; Garbovskiy 2004: 513) can be used:

- cultural equivalents (to replace a cultural word in the SL with a TL one (Newmark 1988: 83) or adaptations (Vinay \& Darbelnet 1995: 39),

- equivalence (to substitute a TL statement for an SL statement which accounts for the same situation, even though there is no formal or semantic correspondence) (Vinay \& Darbelnet 1995: $38)$,

- different types of modulations connected with the use of synonyms, hyponyms, hypernyms, compensations, and proper names reconstructions (Aleksandrova 2018a: 15), 
- calembourisation (from the French word calembour "pun"); a deformation procedure, which deals both with the replacement of signs and/or punning mechanisms in TT (Aleksandrova 2018a: 17).

We can distinguish the following types of calembourisation connected with the replacement of mechanism: homonymisation, paronymisation, polysemantisation, and phraseologisation (Aleksandrova 2018a: 17).

As examples, consider the translated versions of this pun from the animated film "Early man" (2018):

\section{Example 7}

\begin{tabular}{|c|c|c|}
\hline SL (Eng.) & TL (Rus.) dubbing & Gloss \\
\hline $\begin{array}{l}\text { - All right, secure the valley. } \\
\text { Start mining ore. } \\
\text { - Or what, Lord Nooth? } \\
\text { - Ore, you fool! Start mining } \\
\text { the ore. The metal that's in the } \\
\text { ground. }\end{array}$ & $\begin{array}{l}\text { - Хорошо, окружить долину и } \\
\text { начать искать породу. } \\
\text { - Какую погоду, Лорд Нос? } \\
\text { - Глупый, начать искать } \\
\text { породу. Этот металл из земли. }\end{array}$ & $\begin{array}{l}\text { All right, surround the valley } \\
\text { and start looking for ore. } \\
\text { Which weather, Lord Nooth? } \\
\text { Full, start looking for the ore. } \\
\text { The metal that's in the ground. }\end{array}$ \\
\hline
\end{tabular}

\section{Example 8}

\begin{tabular}{|c|c|c|}
\hline SL (Eng.) & SL (Fr.) subtitling & Gloss \\
\hline $\begin{array}{l}\text { - All right, secure the valley. } \\
\text { Start mining ore. } \\
\text { - Or what, Lord Nooth? } \\
\text { - Ore, you fool! Start mining } \\
\text { the ore. The metal that's in the } \\
\text { ground. }\end{array}$ & $\begin{array}{l}\text { - Bien, on boucle la vallée et on } \\
\text { commence à creuser la mine. } \\
\text { - Mine de quoi ? } \\
\text { - Imbécile. On commence à } \\
\text { creuser la mine. Pour récupérer } \\
\text { le métal sous terre. }\end{array}$ & $\begin{array}{l}\text { All right, surround the valley } \\
\text { and start looking for ore. } \\
\text { Mine/face expression of what? } \\
\text { Full. Start looking for the ore. } \\
\text { To take the metal from the } \\
\text { ground. }\end{array}$ \\
\hline
\end{tabular}

Here, the homonymy of words ore and or, used in the original, is kept in the French version, where the homonyms la mine "face expression" and la mine "mine" were used. But the homonymy (ore/or) is replaced in Russian, where the translator used the paronyms, nopoda ("ore") and погода ("weather"). Homonymisation and paronymisation often replace each other in the ST and the TT.

It should be noted that phraseologisation can be both a mechanism replacement procedure and a sign replacement procedure.

In translations of the pun below, based on the use of the paronyms rash and rasher, the punning mechanism is preserved in the Russian version, using вотчина ("patrimony") and ветчина ("ham"). The mechanism is, however, changed into phraseologisation in the French version, where the literal interpretation of the idiom rentrer dans le lard "enter the bacon" (gloss.) meaning to "attack, beat somebody," is used to create the comic effect:

\section{Example 9}

\begin{tabular}{|c|c|c|}
\hline SL (Eng.) & TL (Rus.) dubbing & Gloss \\
\hline $\begin{array}{l}\text { - My word. Is that a pig they } \\
\text { just put in goal? }\end{array}$ & $\begin{array}{l}\text { - Вот это да, это что, кабан у } \\
\text { них на воротах? }\end{array}$ & $\begin{array}{l}\text { My word. Is that a pig they just } \\
\text { put in goal? }\end{array}$ \\
\hline - Have to say that's rather rash. & $\begin{array}{l}\text { - Теперь } \quad \text { ворота } \quad-\quad \text { его } \\
\text { вотчина! }\end{array}$ & \\
\hline $\begin{array}{l}\text { - Rasher. Do you get it? } \\
\text { Bacon. }\end{array}$ & - Ветчина! Это игра слов! & Ham! This is a word game! \\
\hline
\end{tabular}


In this translation version, the paronyms вотчина ("patrimony") and ветчина ("ham") are used to create a pun.

\section{Example 10}

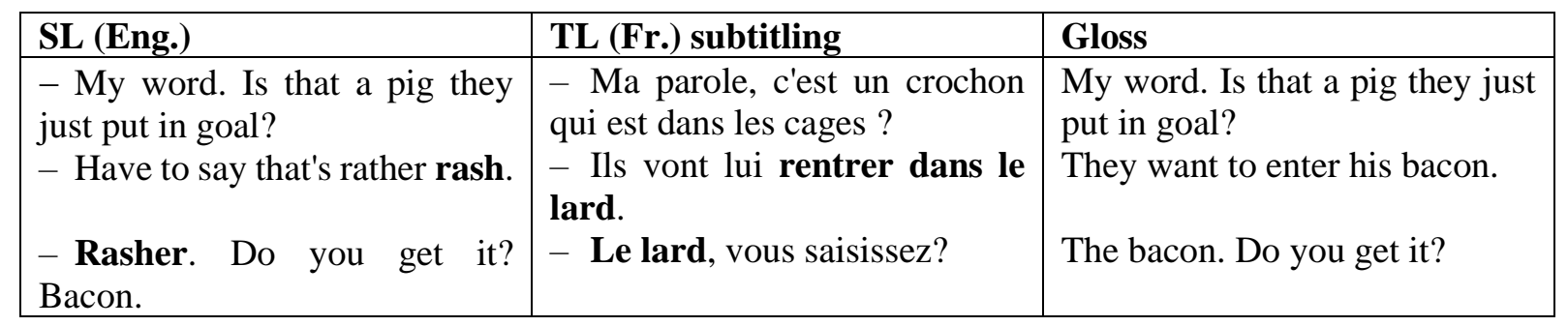

These types of deformations are appropriate and justified when there is no other way to preserve the atmosphere of the original (union or attempted fusion of the reality of the perceiver and the perceived, both in the ST and the TT).

The other principal concept is oscillation, meaning a combination of opposing phenomena in a single whole (Goryunov 2017) or between positions with diametrically opposed ideas operating like the pulsating polarities of a colossal electric machine, propelling the world into action (Turner 2015). Oscillation is more obvious in the translation of realia-based puns.

\section{Translation of realia-based puns}

Preserving the "atmosphere" of the original and finding the right balance between freedom and restriction becomes a challenge in the case where one of the core signs of the pun is represented by realia. Audiovisual products are nowadays designed for international audiences, and their success is partly ensured by their being equipped with a heavy load of transcultural references (Tănase 2018: 104).

Apart from puns, translators choose different ways of translating realia. Researchers identify different sets of methods for translating realia: periphrasis, transcription, omission, and adaptation, or adaptive transposition (parabola) (Garbovskiy 2004: 485); transliteration/transcription (full or partial), translational periphrasis, use of a word denoting something close in function to a foreign language realia, hyponymic and generalised approximate translation (Fyodorov 2002: 207); making up a new word, explaining the meaning of the SL expression, preserving the SL term intact, finding a word in TL which seems similar to or has the same relevance as the SL word (Graedler 2000: 3); official equivalent, retention, specification, direct translation, generalisation, substitution (cultural substitution and paraphrase), omission (Pedersen 2005: 3-9); exotism, cultural borrowing, calque, lexical recreation, generalisation, communicative translation, deletion, cultural substitution, and cultural transplantation (Haywood et al. 2009: 73).

It was revealed that these methods are not always successful in cases where realia is used as one of the signs of the pun core. The last procedure involving "finding a word in TL which seems similar to or has the same relevance as the SL word" (Graedler 2000: 3) can be used for audiovisual translation of realia-based puns. Harvey (2000) mentions the same procedure, calling it "functional equivalence". This refers to the use of a referent in the TL culture, whose function is similar to that of the source language (SL) referent (Harvey 2000: 2-6). Newmark (1988: 83) uses the term "cultural equivalent", which means replacing a cultural word in SL with a TL one and Haywood et al. (2009: 73) use the terms "cultural substitution" and "cultural transplantation". 
It should be noted that the phraseological unit and the realia belong to non-equivalent vocabulary. Vlakhov \& Florin (1986: 50) note that non-equivalent vocabulary involves lexical (and phraseological) units that do not have constant, context-independent equivalents in the TL. The authors also note that phraseological units are considered as realia when we deal with: 1) typical stable phrases of all types, including idioms, proverbs, and sayings, many of which are characterised by national and/or historical connotation, and 2) phraseological units containing realia (Vlakhov \& Florin 1986). Veisbergs develops eight translation strategies for idiom-based puns in literary works: equivalent idiom transformation, loan transformation, extension, analogue idiom transformation, substitution, compensation, omission, and metalingual comment (Veisbergs 1997: 164-171). But not all of them are applicable to audiovisual texts (Dore 2010: 21).

The comparative analysis of the originals and translations of realia-based puns revealed three types of deformations connected with the replacement of a sign in "quasi-translation" strategy: quasi-localisation, quasi-globalisation, and quasi-glocalisation.

\subsection{Quasi-localisation}

The term "quasi-localisation" includes two components: "quasi" ("apparently but not really, seemingly") and "localisation". It should be noted that the term "localisation" is widely used in translation theory. Localisation is considered to be a professional procedure for adapting linguistic, cultural and technical content (Gambier 2016: 61); that is, it is a type of lexicalsemantic adaptation of the text of the original, taking into account the language and culture of the translation user (Garbusenok \& Znachenok 2001: 134).

In some cases, it is argued that there is no special need to introduce a new term. Y. Gambier (2016) notes:

Если мы будем считать, что локализация заключается в адаптации текста с учетом местных (т. е. принимающей культуры) лингвистических и культурных норм и обычаев, то эта идея хорошо закрепилась в переводоведении и в практике перевода (см. динамическую эквивалентность Найды [Nida, p. 159]; инструментальный перевод Норд [Nord, p. 52]; скрытый перевод Хауз [House] или одомашнивание Венути [Venuti, p. 19-20]), добавлять новый термин (локализация) было бы излишним, если не считать того, что мы явно отходим от традиционного смысла перевода, принятого в рамках парадигмы эквивалентности.

[If we assume that localisation consists of adapting the text to the local (i.e., receiving culture) linguistic and cultural norms and customs, then this idea is well established in translation studies and translation practice (see the dynamic equivalence (Nida 1964: 159); instrumental translation (Nord 1997: 52); hidden translation (House 1997) or domestication (Venuti 2008: 19-20), and adding a new term (localisation) would be superfluous, except for the fact that we are clearly moving away from the traditional meaning of the translation adopted in the framework of the equivalence paradigm].

(Gambier 2016: 62)

But the term "localisation" is gaining more and more popularity, and in some situations, translation and localisation cannot be interchangeable concepts, since they have different goals: for the first one involves translating the essence and meaning of the message, but the second one involves conveying the original meaning while taking into account many factors that may affect the experience of the product (see examples of localisation in animated films on Brightside.me 2018). In the framework of the "quasi-translation" strategy, the term "quasilocalisation" is used to denote the deformation procedure used for the translation of a pun, when taking into account the culture of the translation user. 
Quasi-localisation is a type of "adaptation": "the intended substitution of the objective situation" (Garbovsky 2004: 403). For example, (Rus.) пионер "pioneer" (here pioneer is a member of the Pioneer organisation of the Soviet Union (Russian realia)/(Eng.) Boy Scout. The fundamental difference is that the term "quasi-localisation" is used to refer to a pun as a speech unit; the term "adaptation" is used in relation to realia as a language unit.

We identified two types of deformation operations within the framework of quasilocalisation of a pun based on realia in the TL: 1) replacing realia in SL with a TL one (adaptation), and 2) replacing realia or phraseological unit in the SL with a TL phraseological unit (phraseologisation). Consider examples of the use of deformations in detail:

Adaptation (replacing the SL realia with a TL one). Consider an example from the animated film "Early man" (2018):

\section{Example 11}

\begin{tabular}{|l|l|l|}
\hline SL (Eng.) & TL (Rus.) dubbing & Gloss \\
\hline - Oh-ho! The Stone Age team is & - Каменный век по- & The Stone Age team is really \\
really coming together, Bryan. & настоящему собрался, Брайн! & coming together, Bryan. \\
- You're not wrong, Brian. It's & - Да, Брайн, похоже, что & Yes, Brian, it seems that the \\
like Early Man, united. That's & дикари сегодня в зените! & savages are at the Zenith today! \\
another joke there, Brian. & Неплохо пошутил, Брайн! & Good joke, Brian. \\
\hline
\end{tabular}

In this case, the translator uses adaptation (replacing the realia in the SL with the TL realia): the name of the football club, "Manchester United," (ST) in the TT is replaced with the name of the Russian football club, "Zenith", while the punning mechanism remains the same - in both cases, homonymy is used.

This change is implausible, because "Manchester United's" red uniform, which is demonstrated in the film, differs from the blue uniform of "Zenith". This replacement was made to reproduce the SL pun in the TL.

Phraseologisation (the use of the phraseological unit in TT). The comparative analysis of the original puns, used in movies and animated films and their Russian and French translations, revealed that the use of phraseological units when translating puns based on realia, is more common for the French tradition than for the Russian. For example, the above pun based on realia ("Manchester United") was translated into French using phraseological unit "bruts de décoffrage" (meaning "row"):

\section{Example 12}

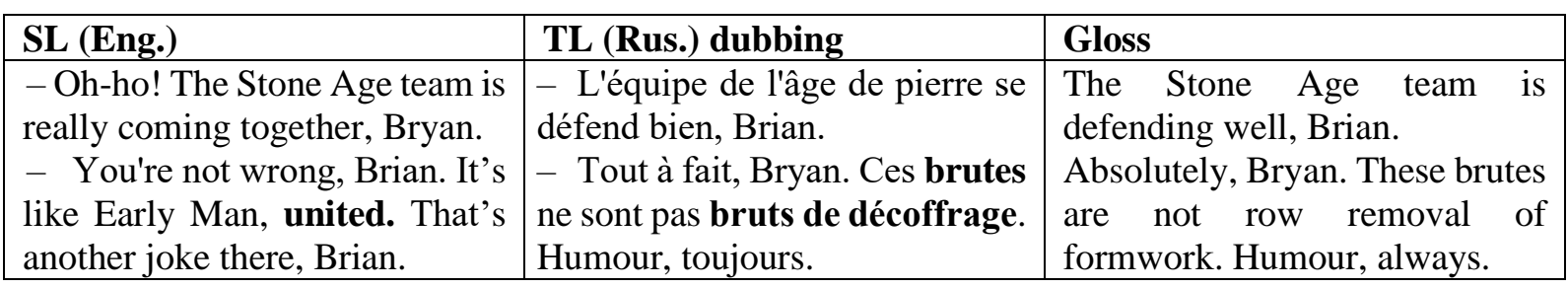

In this case, phraseologisation is connected with the replacement of the sign (realia in ST was replaced with the phraseological unit in TT), since the punning mechanism is based on the use of paronyms bruts (de décoffrage)/brutes "rough".

Phraseologisation can also be connected with the replacement of the punning mechanism. Consider an example from the animated film "Madagascar" (2005): 


\section{Example 13}

\begin{tabular}{|l|l|l|}
\hline SL (Eng.) & TL (Fr.) subtitling & Gloss \\
\hline $\begin{array}{l}\text { Hoover Dam (damn)!! We're } \\
\text { still in New York. }\end{array}$ & $\begin{array}{l}\text { Mille tribords ! Toujours New } \\
\text { York. }\end{array}$ & Starboard side! Still New York. \\
\hline
\end{tabular}

Here the original pun is based on the use of homonyms: the noun, dam [dcem] as a component of realia "Hoover Dam," and the interjection "damn" [doem]. In the French translation, it was used in the transformation of the phraseological unit: "mille sabords!" ("shiver me timbers!") was transformed into "mille tribords" (tribord is "starboard side").

Thus, the use of phraseological units can be a transformation associated both with the replacement of a sign when the polysemy of one of the components of the phraseological unit or its similarity/analogy with other signs is played out, as well as with the replacement of the mechanism (e.g., transformation or literal interpretation of phraseological units).

\subsection{Quasi-globalisation}

Quasi-globalisation occurs when a pun based on the use of realia or a phraseological unit in the SL is replaced with a pun which contains neither realia nor phraseological unit in the TL.

In the example from the animated film "Early man" (2018), in order to create a pun, an allusion to the British realia Old Bill (the police) which has a duck as a mascot, is used in the SL. In this case, the intersemiotic pun is presented: Old Bill (audio)/ the image of a duck (visuals). In the Russian translation of this pun, the SL realia is omitted, with the translator using a paronymisation (это ж утка "it's a duck"/эта шутка "it's a joke") instead:

\section{Example 14}

\begin{tabular}{|c|c|c|}
\hline SL (Eng.) & TL (Rus.) dubbing & Gloss \\
\hline $\begin{array}{l}\text { - Look at that. Caught by the } \\
\text { old bill. } \\
\text { - Oh, Bryan, that's comedy } \\
\text { bronze. Well done, my friend. }\end{array}$ & $\begin{array}{l}\text { - Вы посмотрите - это ж } \\
\text { утка! } \\
\text { - Да, Брайн, эта шутка на } \\
\text { бронзу, поздравляю! }\end{array}$ & $\begin{array}{l}\text { Look at that. This is a duck! } \\
\text { Yes, Bryan, this joke is worth a } \\
\text { bronze medal. Congratulations! }\end{array}$ \\
\hline
\end{tabular}

In the French version, "quasi-localisation" was used as the procedure. The translator used phraseologisation involving the literal interpretation of the phraseological unit "prise de bec": "fight of beaks" (gloss.), "wrangle, squabble":

\section{Example 15}

\begin{tabular}{|l|l|l|}
\hline SL (Eng.) & TL (Fr.) subtitles & Gloss \\
\hline $\begin{array}{l}\text { - Look at that. Caught by the } \\
\text { old bill. }\end{array}$ & $\begin{array}{l}\text { Regardez-moi cette prise de } \\
\text { - Oh, Bryan, that's comedy }\end{array}$ & $\begin{array}{l}\text { Look at that. This is a fight of } \\
\text { beaks. } \\
\text { bronze. Well done, my friend. }\end{array}$ \\
$\begin{array}{l}\text { médaille de bronze du rire. } \\
\text { Brian, you deserve the bronze } \\
\text { medal of laughter. }\end{array}$ \\
\hline
\end{tabular}

Thus, it can be concluded that in different translation traditions and modes for the transmission of the same pun complicated by realia, different types of deformations can be used. While the Russian tradition is often characterised by the use of adaptation (realia) in the TT, for the French tradition, it is more common to use phraseological units in the TT. 


\subsection{Quasi-glocalisation}

The term "quasi-glocalisation" can be used to denote a translation procedure of a single realiabased pun, as well as a translation strategy.

\subsubsection{Quasi-glocalisation as a single pun translation procedure}

Consider the episode from the animated film "Madagascar" (2005):

\section{Example 16}

\begin{tabular}{|l|l|l|}
\hline SL (Eng.) & TL (Rus.) dubbing & Gloss \\
\hline $\begin{array}{l}\text { - Did that say “Grand Central } \\
\text { Station" or "my aunt's } \\
\text { constipation"? }\end{array}$ & $\begin{array}{l}\text { Центральный” "кала “бошьй } \\
\text { астральный"? }\end{array}$ & $\begin{array}{l}\text { She said “Grand Central” or } \\
\text { "astral bushlat”? }\end{array}$ \\
\hline
\end{tabular}

Here "bushlat" is Russian realia meaning sailor's jacket (see Amiri \& Madaeni 2014: 94). When translating the pun based on the use of paronyms central station/constipation, the Russian translator used the same punning-mechanism Большой Центральный/бушлат астральный. To reproduce realia from the first sign Grand Central Station (Terminal), the translator makes a loan translation, Grand Central/Большой Центральный, keeping the sign, globalised in the TT, but adds realia, бушлат, when reproducing the second sign, making it localised in the TT. Thus, quasi-globalisation and quasi-localisation are used to reproduce the original pun.

\subsubsection{Quasi-glocalisation as the general strategy of audiovisual translation of animated films}

Quasi-localisation and quasi-globalisation are considered to be the procedures for the translation of a single pun. The integrated use of quasi-localisation and quasi-globalisation forms the general strategy for translation of a work containing two or more puns, for which the term "quasi-glocalisation" is proposed in this paper. Gambier (2016: 62) notes that the term "glocalisation" is usually referred to marketing, where it is used to describe situations where a product, “несмотря на сходство с местными товарами, такой продукт сохранит ряд черт оригинального глобального продукта" [despite its similarities with local products, retains a number of features of the original global product]. The main aim of quasi-glocalisation as an audiovisual translation strategy of a pun-containing work is to find the right balance between the need to adapt the translation to the target culture and to preserve the culturally marked components of the original.

In metamodernism, the search for balance is connected with the oscillation between the need to keep TT localised, and the need to keep TT globalised at the same time. Quasiglocalisation refers to the oscillation between two poles: "quasi-localisation" and "quasiglobalisation", and reproducing the "atmosphere" of the original.

\section{Conclusion}

The results of this study demonstrate that the application of metamodern and semiotic principles to the translation of puns is feasible, because it helps to identify the key to a successful translation of an animated film containing puns, which involves finding the right balance when oscillating between quasi-localisation and quasi-globalisation, as well as reproducing the "atmosphere" involving ambiguity and the non-evident content in the TL. According to a metamodern-semiotic approach, reaching the right balance when oscillating between the need to keep the TT localised and globalised at the same time, and finding a single source of 
atmospheres in the ST and TT to express their unity in spite of the differences, are the basic goals of the translation.

The analysis of the research material revealed that the most popular translation strategies, both in Russian and French dubbing and subtitling traditions are: free translation, literal translation, omission, and "quasi-translation". "Quasi-translation" is based on the metamodern idea of changing the rules of the game proposed by the author of the original text, and based on the semiotic approach to the description of the pun structure, can be considered as the most relevant strategy for translating single puns in animated films. Calembourisation is a special translation procedure within the quasi-translation strategy. Calembourisation involves such translation deformation procedures as quasi-localisation, quasi-globalisation, and quasiglocalisation (see Table 1).

Table 1: Audiovisual translation strategies and procedures for animated films, containing puns.

\begin{tabular}{|c|c|c|c|c|}
\hline $\begin{array}{l}\text { general strategy of } \\
\text { work containing } \\
\text { puns translation }\end{array}$ & \multicolumn{4}{|c|}{ quasi-glocalisation } \\
\hline $\begin{array}{l}\text { strategy of pun } \\
\text { translation }\end{array}$ & \multicolumn{4}{|c|}{ quasi-translation } \\
\hline procedure & \multicolumn{4}{|c|}{ calembourisation } \\
\hline type of procedure & \multicolumn{2}{|c|}{ mechanism replacement } & \multicolumn{2}{|c|}{ sign replacement } \\
\hline $\begin{array}{l}\text { realia-based pun } \\
\text { translation } \\
\text { procedures }\end{array}$ & $\begin{array}{c}\text { quasi- } \\
\text { globalisation }\end{array}$ & \multicolumn{2}{|c|}{ quasi-localisation } & $\begin{array}{c}\text { quasi- } \\
\text { globalisation }\end{array}$ \\
\hline \multirow[t]{3}{*}{$\begin{array}{l}\text { realia translation } \\
\text { procedures }\end{array}$} & homonymisation & $\begin{array}{c}\text { phraseologisation } \\
\text { (literal interpretation, } \\
\text { transformation) }\end{array}$ & $\begin{array}{l}\text { phraseologisation } \\
\text { (replacement by a } \\
\text { phraseological unit) }\end{array}$ & $\begin{array}{c}\text { omission of } \\
\text { phraseological } \\
\text { unit }\end{array}$ \\
\hline & paronymisation & & $\begin{array}{l}\text { adaptation } \\
\text { (replacement by a } \\
\text { realia) }\end{array}$ & omission of realia \\
\hline & polysemantisation & & adding a realia & loan translation \\
\hline
\end{tabular}

These procedures can be connected with the replacement of:

1) a punning mechanism (phraseologisation, polysemantisation, homonymisation, paronymisation);

2) signs - adaptation (replacing the SL realia with the TL realia, adding realia in the TT), phraseologisation (replacing SL realia with the phraseological unit in the TT).

"Quasi-localisation" takes place when a pun, based on realia or a phraseological unit, is used to reproduce the original puns in the TL.

"Quasi-globalisation" takes place when a pun based on the use of homonyms, paronyms or polysemous words, which contains neither realia nor phraseological units, is used in the TL to reproduce the original pun based on realia or a phraseological unit. Quasi-glocalisation, as pun translation procedure, involves the use of quasi-localisation and quasi-glocalisation to reproduce the signs making the basis of the pun. As a general strategy for translation of a work containing two or more puns, including ones complicated by realia, it is used to find the right balance between unique and universal, private and general, national and international, local and global. This strategy can be considered to be the most suitable for audiovisual translation of animated films. Quasi-glocalisation, which makes it possible to impart to the artwork some cultural characteristics of the target culture, and at the same time to preserve the "atmosphere" of the original, becomes one of the most relevant strategies of the new translation reality.

This work can be useful for fostering the future synchronic and diachronic comparative analysis of pun translation in animated films in the Russian and the French traditions. It would be interesting to analyse the influence of the target culture on the choice of translation strategies 
and procedures, as well as to find out in what way translation norms and conventions have changed over time.

\section{References}

Abramson, S. (2014). 'Talkson Metamodernism with Seth Anderson'. As It Ought to Be. Website. Retrieved May 22, 2018 from https://asitoughttobe.com/2014/03/12/talks-onmetamodernism-with-seth-abramson-part-3-of-3/.

Aleksandrova, E. M. (2018a). 'Gibridnaya igra kak semiotiko-lyudicheskaya model' perevoda kalambura: strategii, taktiki, preobrazovaniya' [Hybrid game as semiotic-ludical model of the translation of pun: strategies, tactics, procedures]. Vestnik Moskovskogo universiteta. Ser. 22. Teoriya perevoda 3, pp. 3-21.

Aleksandrova, E. M. (2018b). Yazykovaya igra po pravilam i bez (na materiale russkogo, anglijskogo i francuzskogo yazykov) [Play on words by the rules and with no rules (on the material of Russian, English and French languages]: monografiya. M.: KDU, Universitetskaya kniga.

Alexander, R. J. (1997). Aspects of Verbal Humour in English. Tübingen: Gunter Narr Verlag.

Amian, K. (2008). Rethinking Postmodernism(s). Amsterdam, New York: Rodopi.

Amiri, M. A. \& Madaeni, A. A. (2014). 'Klassifikatsiya realiy v russkom i persidskom yazykakh'. [Classification of realities in Russian and Persian]. Vestnik RUDN, seriya Russkiy i inostrannyye yazyki i metodika ikh prepodavaniya No 3, pp. 90-97. (in Russ.).

Attardo, S. \& Raskin V. (1991). 'Script theory revis(it)ed: joke similarity and joke representation model'. Humor 4:3-4, pp. 293-347.

Bassnett, S. (1980). Translation Studies. London \& New York: Routledge.

Böhme, G. (1993) 'Atmosphere as the fundamental concept of a new aesthetics'. Thesis Eleven 36:1, pp. 113-126.

Bolaños García-Escribano, A. (2017). 'Subtitling audiovisual humour: the case of 'early Almodóvar' films during la movida in Spain (1980-1984)', in Martínez Sierra, J. J. \& Zabalbeascoa, P. (eds.), The Translation of Humour / La traducción del humor. MonTI 9, pp. 219-247.

Brisset, F. (2015). 'Doublage et duplicité : traduire l'humour verbal au cinema'. Traduire 232, pp. 5-21.

Bucaria, C. (2017). 'Audiovisual translation of humor', in Attardo, S. (ed.), The Routledge Handbook of Language and Humor, New York \& London: Routledge, pp. 430-444.

Bucaria, C. (2007). 'Humour and other catastrophes: dealing with the translation of mixed-genre TV Series'. Linguistica Antverpiensia 6, pp. 235-254.

Bunnell, N. (2015). 'Oscillating from a distance: A study of metamodernism in theory and practice'. Undergraduate Journal of Humanistic Studies 1, pp. 1-8.

Chiaro, D. (2017). 'Humor and translation', in Attardo, S. (ed.), The Routledge Handbook of Language and Humor, New York, London: Routledge, pp. 414-430.

Chiaro, D. (1992). The Language of Jokes: Analyzing Verbal Play, London \& New York: Routledge.

Chiaro, D. (2010). 'Translating humour in the media', in Chiaro, D. (ed.), Translation, Humour and the Media, London: Continuum, pp. 1-16.

Cosculluela, C. (2003). 'Semiotics and translation studies: an emerging interdisciplinarity'. Semiotica 145 (1-4), pp. 105-137.

De los Reyes Lozano, J. (2017). 'Bringing all the senses into play: the dubbing of animated films for children’. Palimpsestes 30, pp. 99-115. 
De Rosa, G. (2014). 'Back to Brazil: humor and sociolinguistic variation in Rio', in De Rosa, G., Bianchi, F., De Laurentiis, A. \& Perego, E. (eds.), Translating Humour in Audiovisual Texts, Bern/Berlin/Bruxelles/Frankfurt am Main/NewYork/Oxford/Wien: Peter Lang, pp. $105-129$.

Delabastita, D. (1993). There's a Double Tongue: An Investigation into the Translation of Shakespeare's Wordplay, with Special Reference to Hamlet. Amsterdam: Rodopi.

Delabastita, D. (1997). 'Introduction', in Delabastita, D. (ed.), Traductio: Essays on Punning and Translation, London: Routledge, pp. 1-22.

Díaz Pérez, F. J. (2017). 'The translation of humour based on culture bound terms in Modern Family. A cognitive-pragmatic approach', in Martínez Sierra, J. J. \& Zabalbeascoa, P. (eds.), The Translation of Humour / La traducción del humor. MonTI 9, pp. 49-75.

Dore, M. (2019). 'Multilingual humour in audiovisual translation. Modern Family dubbed in Italian'. European Journal of Humour Research 7 (1), pp. 52-70.

Dore, M. (2009). 'Target language influences over source texts: A novel dubbing approach in The Simpsons, first series', in Federici, F. (ed.), Translating Voices for Audiovisual, Rome: Aracne Editrice, pp. 136-156.

Dore, M. (2010). 'The audiovisual translation of fixed expressions and idiom-based puns', in Valero Garcés, C. (eds.), Dimensions of Humor: Explorations in Linguistics, Literature, Cultural Studies and Translation, Valencia: University of Valencia Press, pp. 361-386.

Eco, U. (1976). A Theory of Semiotics. Bloomington: Indiana University Press.

Eco, U. (2001). Experiences in Translation. Toronto, Buffalo, London: University of Toronto Press.

Eco, U. (2003). Skazat' pochti to zhe samoye. Opyty o perevode [Saying Almost the Same Thing: Experience in Translation] (Transl. from Italian 'Dire quassi la stessa cosa'). AST. (in Russ.)

Febleron, N. (2012). 'To engage in Llterature'. Notes on Metamodernism. Website. Retrieved March 23, 2017 from http://www.metamodernism.com/2012/05/29/to-engage-inliterature/.

Freinacht, H. (2015). You're not metamodern before you understand this. Part 1: Game Change. Metamoderna. Website. Retrieved February 10, 2018 from http://metamoderna.org/yourenot-metamodern-before-you-understand-this-part-1-game-change?lang=en.

Fuentes, A. (2010). 'On the (mis/over/under)translation of the Marx Brothers' humour', in Chiaro, D. (ed.), Translation, Humour and the Media, London: Continuum, pp. 175-192.

Fyodorov, A. V. (2002). Osnovy obshchey teorii perevoda [Fundamentals of the General Theory of Translation]. (5-ye izd.). SPbGU; Moskva: Filologiya TRI.

Gabrusenok, M. S. \& Znachenok, V. S. (2016). 'Osobennosti perevoda multiplikatsionnogo filma $\mathrm{s}$ angliyskogo yazyka na russkiy i s russkogo na angliyskiy' [Features of the translation of the animated film from English to Russian and from Russian to English], in Ulanovich, O. I. (ed.), Gumanitarnyye tekhnologii v obrazovanii i sotsiosfere: sb. nauch. st. Minsk: Izd. tsentr BGU, pp. 133-139.

Gambie, I. (2016). 'Perevod i perevodovedeniye na perekrestke tsifrovykh tekhnologiy' [Translation practice and theory at the cross-roads of digital technologies]. Vestnik SPbGU. Seriya 9. Filologiya. Vostokovedeniye. Zhurnalistika. Vyp. 4, pp. 56-74.

Garbovskiy, N. K. (2004). Teorija perevoda [The Theory of Translation]. Moscow: Izd-vo Moskovskogo universiteta.

Goryunov, V. (2017). 'Metamodernizm i sinkretika: popytka sistematizatsii' [Metamodernism and syncretics: an attempt to systematize]. Russkiy metamodern. Teoriya. Website. Retrieved 8 April, 2018 from http://metamodernizm.ru/syncretism/.

Gottlieb, H. (1997a). Subtitles, Translation \& Idioms. Copenhagen: University of Copenhagen $\mathrm{PhD}$ thesis. 
Gottlieb, H. (1997b). 'You got the picture? On the polysemiotics of subtitling wordplay', in Delabastita, D. (ed.), Traductio. Essays on Punning and Translation, Manchester: St Jerome, pp. 207-232.

Graedler, A. L. (2000). 'Cultural shock'. Retrieved March 23, 2017 from http://www.hf.uio.no/iba/nettkurs/translation/grammar/top7culture.html.

Guiraud, P. (1976). Les jeux de mots. Paris: Presses Universitaires de France.

Harvey, M. (2003). 'A beginner's course in legal translation: the case of culture-bound terms'. Retrieved February 10, 2018 from http://www.tradulex.org/Actes2000/harvey.pdf.

Haywood, L., Thomson, M. \& Hervey, S. (2009). Thinking Spanish Translation. A Course Translation Method: Spanish to English. 2nd ed. London \& New York: Routledge.

Henry, J. (2003). La traduction des jeux de mots. Paris: Presses Sorbonne Nouvelle.

House, J. (1997). Translation Quality Assessment: A Model Revisited. Tübingen: Narr. House.

Jakobson, R. (1959). 'On linguistic aspects of translation', in Brower, R. (ed.), On Translation, Cambridge MA: Harvard University Press, pp. 232-239.

Lew, R. (1996). An Ambiguity-Based Theory of the Linguistic Verbal Joke in English. Poznań: Adam Mickiewicz University PhD thesis.

López González, R. C. (2017). 'Humorous elements and translation in animated feature films: DreamWorks (2001-2012)', in Martínez Sierra, J. J. \& Zabalbeascoa, P. (eds.), The Translation of Humour / La traducción del humor, MonTI 9, pp. 279-305.

Low, P. A. (2011). 'Translating jokes and puns'. Perspectives 19:1, pp. 59-70.

Manca, E. \& Aprile, D. (2014). 'Culture, language, and humour: adapting wordplay in the Italian version of Wreck-it-Ralph', in De Rosa, G., Bianchi, F., De Laurentiis, A. \& Perego, E. (eds.), Translating Humour in Audiovisual Texts, Bern/Berlin/Bruxelles/Frankfurt am Main/NewYork/Oxford/Wien: Peter Lang, pp. 155-172.

Martínez Sierra, J. J. \& Zabalbeascoa, P. (2017). 'Humour as a symptom of research trends in translation studies', in Martínez Sierra, J. J. \& Zabalbeascoa, P. (eds.), The Translation of Humour / La traducción del humor, MonTI 9, pp. 9-27.

Minutella, V. (2014). 'Translating verbally expressed humour in dubbing and subtitling: the Italian versions of Shrek', in De Rosa, G., Bianchi, F., De Laurentiis, A. \& Perego, E. (eds.), Translating Humour in Audiovisual Texts, Bern/Berlin/Bruxelles/Frankfurt am Main/NewYork/Oxford/Wien: Peter Lang, pp. 67-89.

Molina, L. \& Hurtado, A. A. (2002). 'Translation techniques revisited: A dynamic and functionalist approach'. Meta 47:4, pp. 498-512.

Morris, C. W. (1938). 'Foundations of the theory of signs'. International Encyclopedia of Unified Science vol. 1, no. 2, Chicago: University of Chicago Press.

Newmark, P. (1988). Approaches to Translation. Hertfordshire: Prentice Hall.

Nida, E. (1964). Toward a Science of Translating: With Special Reference to Principles and Procedures Involved in Bible Translating. Leiden, E. J. Brill Publ.

Nord, C. (1997). 'A functional typology of translations', in Trosborg A. (ed.), Text Typology and Translation, Amsterdam, Philadelphia, John Benjamins Publ., pp. 43-66.

Pavlov, A. (2018). 'Obrazy sovremennosti' [Images of modernity]. Logos 28 (16), pp. 1-19.

Pedersen, J. (2005). 'How is culture rendered in subtitles?'. MuTra 2005 - Challenges of Multidimensional Translation: Conference Proceeding, pp.1-18. Retrieved May 2018 from http://www.euroconferences.info/proceedings/2005_Proceedings/2005_Pedersen_Jan.pdf

Pedersen, J. (2011). Subtitling Norms for Television. Amsterdam \& Philadelphia: John Benjamins.

Peirce, C. S. (1934). Collected Papers of C. S. Peirce, Vol. V: The Pragmatism and Scientific Metaphysics of C. S. Peirce. Ed. by Hartshorne, C. \& Weiss, P., Cambridge MA: Harvard University Press. 
Pisek, G. (1997). 'Wordplay and the dubber/subtitler'. AAA - Arbeiten aus Anglistik und Amerikanistik 22:1, pp. 37-51.

Ritchie, G. (2004). The Linguistic Analysis of Jokes. London, Routledge.

Schauffler, S. (2015). 'Wordplay in subtitled films - An audience study', in Zirker, A. \& WinterFroemel, E. (eds.), Wordplay and Metalinguistic / Metadiscursive Reflection, Walter de Gruyter, pp. 229-244.

Schröter, T. (2005). Shun the Pun, Rescue the Rhyme? - The Dubbing and Subtitling of Language-Play in Film. Karlstad: Universitetstryckeriet.

Schröter, T. (2010). 'Language-play, translation and quality - with examples from dubbing and subtitling', in Chiaro, D. (ed.), Translation, Humour and the Media, London \& New York: Continuum, pp. 138-152.

'Seven famous cartoons that were changed in other countries' (2018). Website. Brightside.me. Retrieved July 10, 2019 from https://brightside.me/wonder-films/how-famous-cartoonsare-adapted-for-different-countries-309510/.

Spanakaki, K. (2007). 'Translating humor for subtitling'. Translation Journal 11:2. Retrieved 3 March, 2018 from https://translationjournal.net/journal/40humor.htm

Stecconi, U. (2004). 'Five reasons why semiotics is good for Translation Studies', in Gambier, Y., Shlesinger, M. \& Stolze, R. (eds.), Doubts and Directions in Translation Studies: Selected Contributions from the EST Congress, Lisbon; John Benjamins, pp. 1526.

Tănase, E. V. (2018). 'Realia in subtitling - an intercultural encounter'. Professional Communication and Translation Studies 11, pp. 98-104.

Toury, G. (1986). 'Translation. A cultural-semiotic perspective', in Sebeok, T. A. (ed.), Encyclopedic Dictionary of Semiotics, Berlin \& New York: Mouton de Gruyter, pp. 11111124.

Turner, L. (2015). Metamodernism: A brief introduction. Metamodernism. Website. Retrieved March 23, 2017 from http://www.metamodernism.com/2015/01/12/metamodernism-abrief-introduction/.

van Kesteren, A. (1978). 'Equivalence relationships between source text and target text: towards a typology on the basis of semiotics', in Holmes, J. S., Lambert, J., van den Broeck, R., Janssens, M. \& Lefevere, A. (eds.), Literature and Translation: New Perspectives in Literary Studies, Leuven: Acco, pp. 48-68.

Vandaele, J. (2011) 'Wordplay in translation', in Gambier, Y. \& Van Doorslaer, L. (eds.), Handbook of Translation Studies, Amsterdam \& Philadelphia: John Benjamins, pp. 180 183.

Veisbergs, A. (1997). 'The contextual use of idioms, wordplays, and translation', in Delabastita, D. (ed.), Traductio: Essays on Punning and Translation, Manchester: St. Jerome, pp. 155-176.

Venuti, L. (2008). The Translator's Invisibility: A History of Translation. (2nd ed.) Abingdon, Routledge.

Vermeulen, T. \& Akker, R. (2010). 'Notes on metamodernism'. Journal of Aesthetics and $\begin{array}{llllll}\text { Culture 23 } & \text { Retrieved } & \text { March } & 2017 & \text { from }\end{array}$ http://www.aestheticsandculture.net/index.php/jac/article/view/5677.

Vinay, J.-P. \& Darbelnet, J. (1995[1958]). Stylistique comparée du francais et de l'anglais: Méthode de Traduction. Paris: Didier. Translated and edited by J. C. Sager and M. J. Hamel (1995) as Comparative Stylistics of French and English: A Methodology for Translation. Amsterdam and Philadelphia: John Benjamins.

Vlakhov, S. \& Florin, S. (1986). Neperevodimoe v perevode [Untranslatable in Translation]. ( $2^{\text {nd }}$ edition). M.: Vyssh. shk. . 
Yaguello, M. (2003). Alisa v strane yazyka. Tem, kto khochet ponyat' lingvistiku [Alice in the Country of Language. To Understand Linguistics] (Translated from French). M.: Yeditorial URSS.

Yousef, T. (2017). 'Modernism, postmodernism, and metamodernism: A critique'. International Journal of Language and Literature 5 (10), pp. 33-43.

Zabalbeascoa, P. (1996). 'Translating jokes for the dubbed television situation comedies'. The Translator 2.2, pp. 235-257.

\section{Sources}

Hahn D. (Producer), \& Allers R., Minkoff R. (Director). (1994). Animated musical film: The Lion King [DVD]. USA: Walt Disney Pictures, Walt Disney Feature.

Murdocca M. (Producer), \& Tartakovsky G. (Director). (2016). 3D computer animated comedy film: Hotel Transylvania 2 [DVD]. USA: Sony Pictures Animation.

Lord P., Sproxton D., Park N., Shelley C., Beek R. (Producer), \& Park N. (Director). (2018). Stop-motion animated comedy film: Early Man [VHS]. United Kingdom: Aardman Animations, UK Film Council.

Soria M. (Producer), \& Darnell E., McGrath T. (Director). (2005). Computer-animated adventure comedy film: Madagascar [DVD]. USA: DreamWorks Animation, PDI/DreamWorks, Sony Pictures Imageworks, Reel FX Creative Studios. 